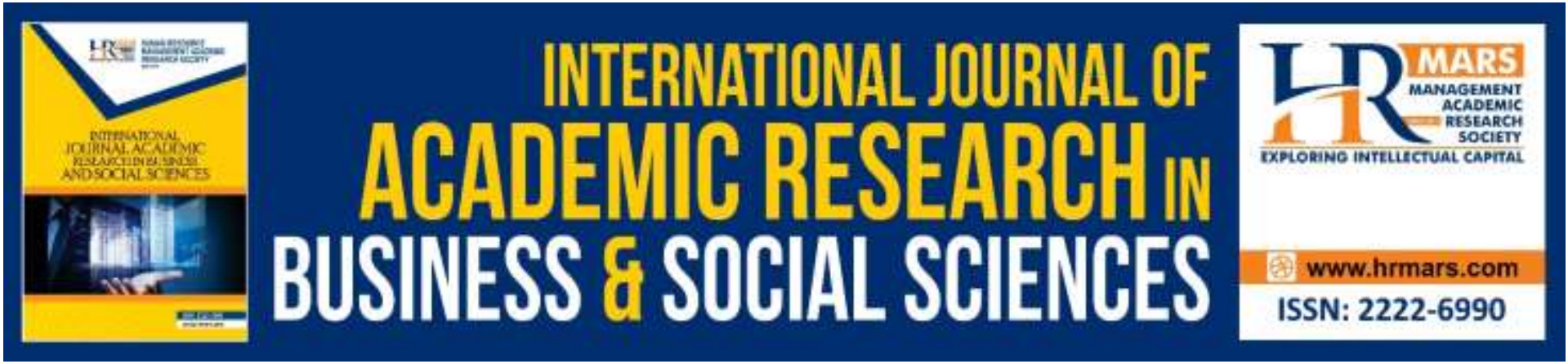

\title{
Preliminary Insights on Investigating Existing Mobile Ethics through Mobile Learning for a Local Context
}

Shamsul Arrieya Ariffin, Ismail Yusuf Panessai, Abu Bakar Ibrahim, Ashardi Abas, Faiz Daud, Muh Anshar

To Link this Article: http://dx.doi.org/10.6007/IJARBSS/v9-i9/6465

DOI:10.6007/IJARBSS/v9-i9/6465

Received: 19 July 2019, Revised: 05 August 2019, Accepted: 29 August 2019

Published Online: 08 September 2019

In-Text Citation: (Ariffin et al., 2019)

To Cite this Article: Ariffin, S. A., Panessai, I. Y., Ibrahim, A. B., Abas, A., Daud, F., \& Anshar, M. (2019). Preliminary Insights on Investigating Existing Mobile Ethics through Mobile Learning for a Local Context. International Journal of Academic Research in Business and Social Sciences, 9(9), 1312-1319.

Copyright: (C) 2019 The Author(s)

Published by Human Resource Management Academic Research Society (www.hrmars.com)

This article is published under the Creative Commons Attribution (CC BY 4.0) license. Anyone may reproduce, distribute, translate and create derivative works of this article (for both commercial and non-commercial purposes), subject to full attribution to the original publication and authors. The full terms of this license may be seen at: http://creativecommons.org/licences/by/4.0/legalcode

\section{Vol. 9, No. 9, 2019, Pg. 1312 - 1319}

Full Terms \& Conditions of access and use can be found at http://hrmars.com/index.php/pages/detail/publication-ethics 


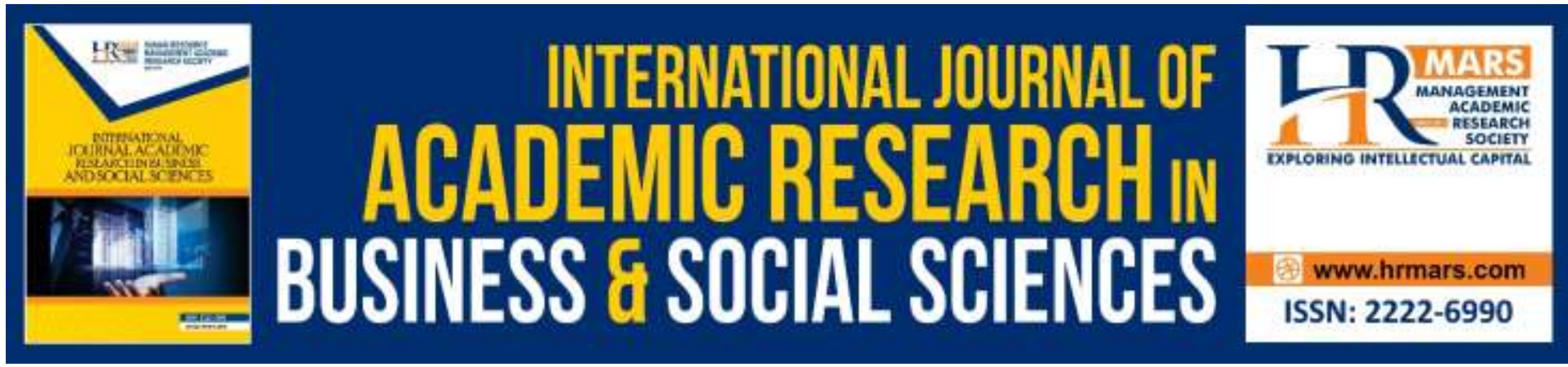

\title{
Preliminary Insights on Investigating Existing Mobile Ethics through Mobile Learning for a Local Context
}

\section{Shamsul Arrieya Ariffin, Ismail Yusuf Panessai, Abu Bakar Ibrahim, Ashardi Abas}

Faculty of Art Computing and Creative Industry, Sultan Idris Education University, Malaysia

\section{Faiz Daud}

Faculty of Medicine, National University Malaysia, Cheras, Kuala Lumpur, Malaysia

\section{Muh Anshar}

Faculty of Electrical Engineering, University of Hasanuddin, Makassar, Indonesia

\begin{abstract}
With the advancement of technology, considerable effort has been made to implement the utilization of mobile technology in learning, especially in STEM related subjects. However, this raises another issue in that the question of ethics when using these kinds of technology has not been addressed for the local context. Based on the current research, participants are concerned about the ethics of mobile technology. Thus, this research is conducted to investigate and identify the mobile ethics of students through mobile learning in a local context. The methodology used in this research is largely qualitative with students from a local university and analysed using thematic analysis. The preliminary findings shed light on the issue of ethics in mobile learning for the local context.
\end{abstract}

Keywords: Mobile Technology, Stem, Themes, Mobile Learning, Ethics, Local Context

\section{Introduction}

Nowadays, university students have a least one mobile phone in their possession. According to Ariffin (2014), there is considerable concern about mobile ethics in the classroom, such as the misuse of mobile phones, plagiarism, breach of security, and others. Also, limited research has been conducted concerning mobile ethics (Ariffin \& Dyson, 2013). Consequently, this research helps create awareness about mobile ethics and helps towards implementing mobile learning in the classroom (Ariffin, 2016a; Ariffin, 2016b; Ariffin, 2017; \& Ariffin, 2018a). Based on the guidelines set by the Ministry of Education (2009), students are prohibited from taking any mobile device into the classroom. In the eyes of Malaysians, mobile phones are considered to be objects that will disturb the class if mishandled or used inappropriately. 
Hence, many academics prefer to ban or minimize the use of mobile phones in the classroom (Ariffin \& Dyson, 2013).

\section{Mobile Learning}

Mobile learning or mLearning enables learning that occurs across time and place as learners apply what they learn in one environment to another context (Kukulska-Hulme \& Traxler 2007; Sharples, Taylor \& Vavoula, 2010). Meanwhile, the phenomenon of using mobile devices has an effect on learning and teaching (Ariffin, Yatim, \& Daud, 2019; Ariffin, 2016a; Ariffin, 2016b). A wide variety of mLearning usage is evident in institutions of higher learning in Asia (Dyson, Wishart, \& Andrew, 2017); and, day-by-day, mobile learning usage in education is increasing in Malaysia. The transformation includes from exclusively higher income to lower income use of mobile devices for learning (Embi \& Nordin, 2013; Nordin, Embi, Norman \& Panah 2017). Thus, mobile learning can be embedded in subjects (Ariffin, Ismail, Yatim, \& Sidek, 2018a; Ariffin, Ismail, Yatim, \& Sidek, 2018c), such as STEM related subjects while creating an awareness concerning the ethics.

\section{STEM}

Integrative STEM education is about the teaching and learning of one or more subject areas in schools or any education institution. According to Labov, Reid and Yamamoto (2010), and Sanders (2008), STEM is the purposeful integration of the various disciplines used in solving real-world problems that involve science, technology, engineering, and mathematics as one unit. In this study, STEM could be enhanced by having mobile devices (Traxler \& Crompton, 2016) for the students where the ethical issues have been researched in developed countries (Wishart, 2018).

\section{Lack of Mobile Ethics Study}

Although many ethical concerns have been raised from all levels of the educational system, the study of the ethics involved is still under researched (Andrews, Dyson \& Wishart, 2013). The misuse of mobile devices in the classroom is not new, and the ban on mobile phones in the classroom was introduced because of the disturbance during class sessions. Mobile devices in the classroom raises many concerns, especially among academics who, often, do not view mobile phones as being educational devices for use in the classroom (Ariffin, 2014). One of the reasons why mobile ethics have not been thoroughly researched is because the ethical concerns are difficult to understand and may differ among academics and other users (Spinello, 2013).

\section{Methodology}

This research is largely qualitative with an emphasis on the deeper meaning of data (Silverman, 2013). This study assumes that students already own their own mobile devices and have created some content using their own mobile devices (Ariffin, 2014). The study involves focus group discussions recruited voluntarily. The data have been analysed using NVivo and a thematic analysis approach (Braun \& Clarke, 2006).

\section{Focus Group Discussions}

Initial focus group discussions were conducted to collect data on their current perspectives and experiences of mLearning for STEM. The students were from five focus groups with a total 
of 34 student participants. The students' ages ranged from early twenties to twenty-five years old. Focus group discussions were selected as an appropriate method for data collection from the students as local students are less shy when discussing in groups (Ariffin, 2014) compared to being asked questions individually. The students were from a wide range of STEM subjects (Ariffin, Yatim, Zaibon, Ali, Ibrahim, Sidek, \& Muttalib, 2018b); as demonstrated in Table 1. In this study, semi-structured open-ended questions were deployed, such as:

a. What do you understand about ethics in mobile learning?

b. What are the examples of ethics in mobile learning in your daily life experience?

c. Describe your existing experience using mobile devices for learning?

Table 1. Student Focus Groups

\begin{tabular}{llllll}
\hline & Course & Code & Subject & Course & Nos \\
\hline 1. & $\begin{array}{l}\text { Software } \\
\text { Engineering }\end{array}$ & FG1 & Discrete Maths (FT1) & AC10 & 7 \\
\hline 2. & $\begin{array}{l}\text { Software } \\
\text { Engineering }\end{array}$ & FG2 & $\begin{array}{l}\text { Computer Organization } \\
\text { (FT2) }\end{array}$ & AC10 & 8 \\
\hline 3. & Chemistry & FG3 & Biology (FT3) & AT11 & 7 \\
\hline 4. & Robotics & FG4 & Robotics (FT4) & AT47 & 6 \\
\hline 5. & Computer Design & FG5 & Design (FT5) & AT47 & 6 \\
\hline & Total & & & & 34 \\
\hline
\end{tabular}

Note: 'FG' = Focus Group, for example FG1 = Focus Group 1

Findings Directed to Lack of Awareness about Ethics in Mobile Learning

In this study, the emerging themes generated from the data are demonstrated in Table 2, which shows that there is a lack of awareness about ethics in mobile learning.

Table 2. Emerging Themes

\begin{tabular}{ll}
\hline & Themes \\
\hline 1. & Ethical Concerns about Using Mobile Phones inside the Classroom \\
\hline 2. & Self-Regulated Ethics in Using Mobile Phones \\
\hline 3. & Banning of Mobile Phones Inside the Classroom \\
\hline 4. & Emergency Use \\
\hline 5. & Unsure about Ethics concerning the use of Mobile Phones \\
\hline 6. & The New and Old Generation Difference about using Phones \\
\hline 7 & Unreliable Sources \\
\hline 8 & Cheating in Exams \\
\hline 9 & Misinterpretation of Social Media \\
\hline
\end{tabular}

Lack of Awareness of Ethics about Mobile Learning

Some participants informed the researcher that the ethical considerations were subjective while others were unsure about the implications. Self-regulated ethics was one of the significant approaches revealed in these findings. 
Ethical Concerns about Using Mobile Phones inside the Classroom: There are growing concerns about how mobile phones can be used appropriately inside the classroom. All the focus groups, FG1, FG2, FG3, FG4, and FG5, expressed their concerns. An example:

“...try to focus on studies and don't play with the mobile phone while the lecturer is teaching out front." FG2

Self-Regulated Ethics in Using Mobile Phones: Participants from FG1, FG2, FG3, FG4, and FG5 highlighted how they controlled their usage of mobile devices. An example:

"...we must lower the ring tone or just turn it off; show some respect." FG2

Banning of Mobile Phones Inside the Classroom: There are certain conditions where mobile phones are not allowed to be used. An example:

"During my form 1 to form 5 we were not allowed to bring the phone, but we still brought it secretly so when we had a spot check we hid it." FG1

Emergency Use: Under special circumstances, academics allowed the students to use mobile phones for emergency use. An example:

"... in emergency cases so their parents can contact them." (FG4)

Unsure about Ethics concerning the use of Mobile Phones: Some students are uncertain whether there are any rules for them to follow in learning using mobile devices, such as mobile phones, especially in the use of mobile phones for STEM. An example:

"Actually, I don't really understand about the ethics." FG2

Disconnection of Students from Social Life: Part of the ethical concerns concerning the use of mobile phones inside the classroom is that students can become disconnected from social life with other people. For instance:

"Mobile phones can cause us to become anti-social, we associate less with society around us." FG1

The New and Old Generation Difference about using Phones: Ethics, and behaviour also differentiate the new and old generation. For example:

"Our parents teach us not to use the phone while eating." (FG2)

Unreliable Sources: Ethics on copyrighting is also unclear for some participants, as highlighted by a participant:

"If we want to write... better we ask their permission before we share." (FG3)

Cheating in Exams: Participants expressed their concern about cheating during exams. For instance, FG1 and FG3 mentioned that extra precautions are necessary during exams to prevent students cheating.

Misinterpretation of Social Media: Participants highlighted that social media can be a platform to disseminate false information using mobile devices:

"Taking a picture is allowed but not to send improper content, which may go viral." (FG1) 


\section{Discussion}

In Malaysia, there are limited policies for mobile learning. In this study there were ethical considerations about using mobile devices. This correlated with the UNESCO report by So (2012), who claimed that mobile learning policies are not yet implemented in Malaysia at all institutional levels. Students agreed about the significance of ethics being very important, as, for example, mobile phones have the potential to cause distraction. Self-regulation was one of the most significant aspects to come out of this study (SKMM, 2012). In order to realise mobile learning ethics' policies in the universities, awareness of the ethical considerations must be in place. Therefore, further research needs to be conducted pertaining to ethics in other local contexts, particularly at institutions of higher learning.

\section{Conclusion}

This research showed that although university students could potentially use mobile devices, such as the multimedia functions of mobile phones for developing content for STEM, proper ethical guidelines must be embedded. For instance, ethical guidelines for mobile learning could be introduced, particularly in learning STEM at the Malaysian universities because these are currently absent. The next step will be to investigate the student generated activities and the ethical factors that could impact the implementation in the local context.

\section{References}

Andrews, T., Dyson, L. E., \& Wishart, J. (2015). Advancing ethics frameworks and scenariobased learning to support educational research into mobile learning. International Journal of Research \& Method in Education, 38(3), 320-334.

Ariffin, S. A., Hayati, Yatim, M. H., \& Daud, F. (2019). Identification of Usability Impact of Mobile Learning STEM in a Local University Context. In Proceedings of the 5th International ACM In-Cooperation $\mathrm{HCl}$ and UX Conference (pp. 106-115). ACM.

Ariffin, S. A., Ismail, A., Yatim, M. H., \& Sidek, S. F. (2018a). An Assessment of Culturally Appropriate Design: A Malaysian University Context. International Journal of Interactive Mobile Technologies, 12(2), pp. 207-14.

Ariffin, S. A., Yatim, M. H. M., Zaibon, S. B., Ali, A. Z. M., Ibrahim, A. B., Sidek, S. F., \& Muttalib, M. F. H. A. (2018b). An Investigation of Student Experience of STEM Mobile Learning in a Local Malaysian University. In World Conference on Mobile and Contextual Learning (pp. 36-50).

Ariffin, S. A., Ismail, A., Yatim, M. H., \& Sidek, S. F. (2018c). A Preliminary Investigation of Malaysian Student's Daily Use of Mobile Devices as Potential Tools for STEM in a Local University Context. International Journal of Interactive Mobile Technologies, 12(2), pp. 8091.

Ariffin, S. A. (2017, April). Needs and Potentials for Studying Local Malaysian Culture through Mobile Learning. In Proceedings of the 3rd International Conference on Human-Computer Interaction and User Experience in Indonesia (pp. 60-66). ACM.

Ariffin, S. A. (2018a). Towards a Smart Educational Environment Framework for mLearning in a Malaysian context, In Proceedings of the 4th International Conference on HumanComputer Interaction and User Experience in Indonesia, CHluXiD'18 (pp. 74-81). ACM.

Ariffin, S. A. (2016a). Academics' Perspectives on the Challenges and Opportunities for Student-Generated Mobile Content in Malaysia. International Journal of Mobile and Blended Learning (IJMBL), 8(3), 49-64. 
Ariffin, S. A. (2016b). Investigating the Daily Use of Mobile Phones as Tools to Enhance mLearning for Local Cultural Subjects in the Context of Malaysian Universities. In Mobile and Blended Learning Innovations for Improved Learning Outcomes (pp. 143-158). IGI Global.

Ariffin S. A. (2014), The Contribution of mLearning to the Study of Local Culture in the Malaysian University Context, PhD dissertation, Faculty of Engineering and Information Technology, University of Technology Sydney, Sydney, Australia

Ariffin, S. A., \& Dyson, L. E. (2013). mLearning in Malaysian universities: Local ethical considerations for mobile phone use. Transactions on Mobile Learning, 2, 15-19. Retrieved 10 August 2015, from: http://research.it.uts.edu.au/tedd/anzmlearn/WordPress/wpcontent/uploads/2009/10/mLearning-in-Malaysian-Universities-Local-Ethical-

Considerations-for-Mobile-Phone-Use.pdf.

Dyson, L. E., Wishart, J., \& Andrews, T. (2017). Ethical Issues Surrounding the Adoption of Mobile Learning in the Asia-Pacific Region. In Mobile Learning in Higher Education in the Asia-Pacific Region (pp. 45-65). Springer, Singapore.Ariffin, S.A., Dyson, L.E., \& HoskinsMcKenzie, D. (2012). Content is King: Malaysian Industry Experts' Point of View on Local Content for Mobile Phones. Journal of Mobile Technologies, Knowledge \& Society, 2012 (2012), 1-9.

Embi, M. A., \& Nordin, N. M. (2013). Mobile learning: Malaysian initiatives and research findings. Malaysia: Centre for Academic Advancement, Universiti Kebangsaan Malaysia, 1131.

Kukulska-Hulme, A., \& Traxler, J. (2007). Designing for mobile and wireless learning. Rethinking pedagogy for a digital age: Designing and delivering e-learning, 180-192.

Labov, J. B., Reid, A. H., \& Yamamoto, K. R. (2010). Integrated biology and undergraduate science education: a new biology education for the twenty-first century?. CBE-Life Sciences Education, 9(1), 10-16.

Nordin, N. M., Embi, M. A., Norman, H., \& Panah, E. (2017). A Historical Review of Mobile Learning Research in Malaysia and Its Implications for Malaysia and the Asia-Pacific Region. In Mobile Learning in Higher Education in the Asia-Pacific Region (pp. 137-150). Springer, Singapore.

Sanders, M. E. (2008). Stem, stem education, Stemmania. Science Teaching, 42(5), 62-66.

Sharples, M., Taylor, J., \& Vavoula, G. (2010). A theory of learning for the mobile age. In Medienbildung in neuen Kulturräumen (pp. 87-99). VS Verlag für Sozialwissenschaften.

Silverman, D. (2013). Doing qualitative research: A practical handbook. London: SAGE Publications Limited.

SKMM Guidelines (2012). Content code, SKMM, Malaysia, Retrieved January 2, 2013 from http://www.skmm.gov.my/Resources/Guidelines/Content-Code.aspx

So, H. J. (2012). Turning on mobile learning in Asia: Illustrative initiatives and policy implications. In S. Vosloo \& M. West (Eds.), Policy focus: UNESCO working paper series on mobile learning (Vol. 1). Paris: UNESCO.

Spinello, R.A. (2003). Case studies in information technology ethics. $2^{\text {nd }}$ ed. Upper Saddle River, NJ: Prentice Hall.

Traxler, J., Crompton, H. (2016) Mobile Learning and STEM: Case Studies in Practice, Routledge, doi:10.4324/9781315745831

Braun \& Clarke (2006) Using thematic analysis in psychology. Qualitative Research in Psychology 3(2), pp. 77-101. 
Wishart, J. (2018). Ethical considerations in the incorporation of mobile and ubiquitous technologies into teaching and learning in educational contexts. In Mobile and Ubiquitous Learning (pp. 81-93). Springer, Singapore.

\section{Acknowledgement}

The authors would like to express their appreciation to all the participants. The appreciation extends to the Ministry of Higher Education Malaysia via UPSI, which provided the FRGS grant code: 2017-0074-107-02, and the recent grant from GUP-2017-061 for the involvement of medical students from UKM in this research.

\section{Corresponding Author}

Shamsul Arrieya Ariffin, UPSI, Malaysia, Email: shamsul@fskik.upsi.edu.my. 